Al Qalam: Jurnal Ilmiah Keagamaan dan Kemasyarakatan

Vol. 13, No. 1, 2019

P-ISSN: 1907-4174; E-ISSN: 2621-0681

\title{
REPRESENTASI BIAS GENDER \\ DALAM KITAB FIQH \\ (STUDI TERHADAP KITAB AT-TAQRIB KARYA ABU SYUJA AL ISFAHANI)
}

Oleh:

\author{
Gt. Muhammad Irhamna Husin
}

Dosen Universitas Lambung Mangkurat, Banjarmasin

Kalimantan Selatan

\begin{abstract}
Abstrak
Fiqh yang termuat dalam Kitab klasik dan modern merupakan hasil pemahaman, penyimpulan, dan interpretasi para fuqaha terhadap Alquran dan al-Hadits sebagai respons atas tantangan zamannya saat ini. Wajar apabila kemudian dalam konstruk fiqh terjadi banyak perbedaan dikalangan fuqaha selain masalah-masalah yang telah diketahui dari ajaran agama secara pasti (al-umur al-mulumah min ad-din bi aldarurah). Perbedaan tersebut sesungguhnya merupakan konsekuensi logis dari adanya perbedaan tempat, kondisi sosial-kultural, tantangan zaman, dan latar belakang intelektual serta metodologi yang digunakan oleh seorang faqih. pokok masalah dalam kajian ini adalah : 1) representasi bias gender apa saja yang terdapat dalam kitab at-Taqrib, dan 2) bias gender dalam kitab tersebut dibaca dan dipahami sesuai dengan konteks zamannya dan sekarang. Kajian ini bertujuan untuk mendeskripsikan dan menganalisis bias gender dalam kitab at-Taqrib serta berusaha membaca dan memahaminya sesuai dengan konteks zamannya dan sekarang. Adapun hasil dari penelitian ini diharapkan dapat memberikan kontribusi mengenai cara pembacaan yang tepat terhadap kitab-kitab klasik khususnya kitab-kitab fiqh, yang sesuai dengan kondisi zaman.
\end{abstract}

Kata kunci: Refresentasi, Gender, Kitab Fiqih 
Gt. Muhammad Irhamna Husin: Representasi Bias Gender dalam Kitab Fiqh (Studi Terhadap Kitab At-Taqrib Karya Abu Syuja Al Isfahani

\section{A. Pendahuluan}

Pertengahan abad ke $1 \mathrm{H}$ sampai ke $2 \mathrm{H}$ merupakan periode pembentukan fiqh Islam. ${ }^{1}$ Khalifah Utsman bin Affan mengirim para sahabat untuk mengajarkan Alquran dan Hadits keberbagai negara. Sahabat yang mengajarkan berbeda-beda dalam metode berdakwah. Sehingga dikenal dengan madrasah al-Hadits dikenal dengan mardaras al-Hijaz dan madrasah al-Madinah sedangkan ar-Ra'yu dikenal dengan madrasah al-Iraq dan madrasah Kufah.. ${ }^{2}$

Kedua Madrasah mempunyai metode yang berbeda dalam berijtihad. Madrasah al-Hijaz berpegang teduh dengan Alquran dan Hadits sedangkan alIraq lebih banyak menggunakan logika atau akal. ${ }^{3}$

Madrasah al-Hijaz menggunakan metode Alquran dan Hadits karena berhadapan dengan masyarakat yang homogen ${ }^{4}$. Sebaliknya madrasah al-Iraqi berhadapan dengan masyarakat yang heterogen sehingga mereka berijtihad menggunakan logika atau akal. ${ }^{5}$

Fiqh yang termuat dalam Kitab klasik dan modern merupakan hasil pemahaman, penyimpulan, dan interpretasi para fuqaha terhadap Alquran dan al-Hadits sebagai respons atas tantangan zamannya saat ini. Wajar apabila kemudian dalam konstruk fiqh terjadi banyak perbedaan dikalangan fuqaha

${ }^{1}$ Izomiddin, Pemikiran dan Filsafat Hukum Islam (Jakarta: Kencana, 2018), h. 25 .

${ }^{2}$ Para sahabat yang berdakwah berhasil membina kader masing-masing yang dikenal dengan Thabi'in. Para thabi'in yang dikenal adalah Sa'id bin Musayyab (15-95 H) di Madinah, Atha bin Abi Rabah (27-114H) di Mekkah, Ibrahim-Nakha'i (w. 76 H) di Kufah, al-Hasan al-Basri (21 H/642M-110H/728M) di Basra, Makhul di Syam (Suriah) dan Tawus di Yaman. Lihat di buku PISS KTB and TIM Dakwah Pesantren, Tanya Jawab Islam: Piss KTB (Yogyakarta: Daarul Hijrah Technology, 2015), h. 4409.

${ }^{3}$ Moch Tolchah, Dinamika Pendidikan Islam Pasca Orde Baru: Pendidikan (Lkis Pelangi Aksara, 2015), h. 169.

${ }^{4}$ Homogen adalah struktur sosial yang unsur-unsurnya mempunyai pengaruh yang sama terhadap dunia luar. sedangkan heterogen adalah suatu struktur yang unsurunsurnya mempunyai kedudukan yang berbeda-beda dan kesem[atan setiap unsur pun berbeda juga, baik terhadap kelompok sendiri maupun kelompok lain. Lihat buku Bagja Waluya, Sosiologi: Menyelami Fenomena Sosial di Masyarakat (Bandung: PT Grafindo Media Pratama, 2007).

5 Izomiddin ,Pemikiran dan Filsafat Hukum Islam..., h. 26. 
Gt. Muhammad Irhamna Husin: Representasi Bias Gender dalam Kitab Fiqh (Studi Terhadap Kitab At-Taqrib Karya Abu Syuja Al Isfahani

selain masalah-masalah yang telah diketahui dari ajaran agama secara pasti ( $a l$ umur al-mulumah min ad-din bi al-darurah). ${ }^{6}$

Ibnu Qayyim al-Jauziyyah ${ }^{7}$ Perbedaan tersebut sesungguhnya merupakan konsekuensi logis dari adanya perbedaan tempat, kondisi sosialkultural, tantangan zaman, dan latar belakang intelektual serta metodologi yang digunakan oleh seorang faqih. Dengan kata lain, formulasi figh sangat erat kaitannya dengan, sedikitnya, dua hal, yaitu metodologi (Man-haj al-ijtihad) yang digunakan oleh seorang fiqih dan konteks sosial-kultural yang mengitari kehidupannya (zuruf al-ijtimaiyyah wa as-saqafiyyah). ${ }^{8}$

Salah satu di antara kitab fiqh klasik yang sampai saat ini masih banyak dikaji dan digunakan adalah kitab at-Taqrib atau Gayah al-lkhtisar karya Abu Syuja al-Isfahani (meninggal sekitar 500 H). Bahkan menurut Martin Van Bruinessen, kitab at-Taqrib ini merupakan kitab yang paling populer di antara kitab-kitab lama yang digunakan oleh pesantren-pesantren di Indonesia hingga sekarang karena hampir tidak ada pesantren di Indonesia yang tidak menggunakan kitab ini. ${ }^{9}$ Kitab yang populer dan banyak dikaji di pesantren-pesantren biasanya banyak mempengaruhi pandangan dan praktek hidup masyarakat di Indonesia, khususnya masyarakat santri di pedesaan. Begitu pula dengan kitab at-Taqrib Sebagai kitab yang sangat populer di kalangan pesantren, isinya dapat dipastikan banyak mempengaruhi pandangan dan pemikiran keagamaan masyarakat Indonesia. Padahal kitab at-Taqrib, sebagaimana kitab-kitab fiqh klasik lainnya, ditulis oleh ulama yang hidup dalam masyarakat yang memiliki budaya

${ }^{6}$ Nur Syam, Madzhab-Madzhab Antropologi (Yogyakarta: Lkis Pelangi Aksara, 2007), h. 206.

7 Ibnu Qayyim al-Jauziyyah adalah seorang Imam Sunni, ahli Fiqih yang hidup pada abad ke-13. beliau adalah fiqh bermazhab Hambali.

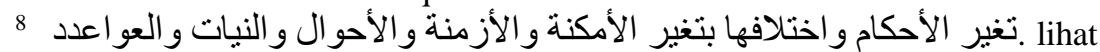
dalam kitab Ibnu Qayyim al-Jauziyyah, I'lam Al-Muwaqqi'in an Rabbil 'Alamin (Beirut: Dar al-Jail, tt), h. 3.

${ }^{9}$ Martin Van Bruinassen, Kitab Kuning: Pesantren Dan Tarekat (Bandung: Mizan, 1995), h. 118-119.

Al Qalam: Jurnal Ilmiah Keagamaan dan Kemasyarakatan

Vol. 13, No. 1, Januari-Juni 2019 
Gt. Muhammad Irhamna Husin: Representasi Bias Gender dalam Kitab Fiqh (Studi Terhadap Kitab At-Taqrib Karya Abu Syuja Al Isfahani

patriarkhi yang kuat sesuai kondisi zamannya ketika itu, sehingga apabila sekarang dibaca dan dipahami secaratekstual apalagi kemudian diikuti sebagai pedoman hidup seharihari, maka ini akan menimbulkan dan melanggengkan budaya patriakhi yangbias gender tersebut dalam masyarakat sekarang. Karena itu, menurut hemat penulis, perlu adanya kajian untuk melakukan pembacaan secara tepat terhadap kitab at-Taqrib sesuai dengan konteks zaman ketika kitab tersebut ditulis.

Atas dasar latar belakang di atas, maka yang menjadi pokok masalah dalam kajian ini adalah : 1) representasi bias gender apa saja yang terdapat dalam kitab at-Taqrib, dan 2) bias gender dalam kitab tersebut dibaca dan dipahami sesuai dengan konteks zamannya dan sekarang.

\section{B. Metode Penelitian}

Kajian ini bertujuan untuk mendeskripsikan dan menganalisis bias gender dalam kitab at-Taqrib serta berusaha membaca dan memahaminya sesuai dengan konteks zamannya dan sekarang. Adapun hasil dari penelitian ini diharapkan dapat memberikan kontribusi mengenai cara pembacaan yang tepat terhadap kitab-kitab klasik khususnya kitab-kitab fiqh, yang sesuai dengan kondisi zaman.

Kajian ini berangkat dari kerangka pikir bahwa proses penentuan hukum figh yang ada pada kitab-kitab, ditentukan oleh metodologi yang digunakan dan konteks sosio-kultural yang ada. Produk pemikiran fiqh berbeda dengan Alquran dan Sunnah Nabi. ${ }^{10}$ Pemikiran dan produk fiqh tidak selamanya dan sepenuhnya relevan untuk setiap zaman dan tempat. Karena itu, kemudian dalam diskursus ilmu fiqh selalu dinyatakan bahwa "fiqh atau hukum dapat berubah seiring dengan perubahan keadaan, zaman, dan tempat". ${ }^{11}$ Perubahan

${ }^{10}$ Warkum Sumitro, Moh Anas Kholish, and In'amul Mushoffa, Konfigurasi Fiqih Poligini Kontemporer: Kritik Terhadap Paham Ortodoksi Perkawinan Poligini di Indonesia (Malang: Universitas Brawijaya Press, 2014), h. 208.

${ }^{11}$ Subhi Mahmasani, Falsafah At-Taqrib Tasyri Fi Al- Islam (Beirut: Dar Alquran Ilm li al-Malayin, 1961), h. 201.

Al Qalam: Jurnal Ilmiah Keagamaan dan Kemasyarakatan Vol. 13, No. 1, Januari-Juni 2019 
Gt. Muhammad Irhamna Husin: Representasi Bias Gender dalam Kitab Fiqh (Studi Terhadap Kitab At-Taqrib Karya Abu Syuja Al Isfahani

fiqh tersebut dalam rangka menyelaraskan dengan tuntutan social dan tantangan zaman yang terus berubah. Idealnya memang dilakukan dengan cara ijtihad, sebagaimana yang telah dilakukan oleh Imam-imam mujtahid atau Imam-imam mazhab. Hanya saja dalam kenyataannya para fuqaha tidak selalu melakukan ijtihad (sendiri) dalam menyusun kitab fiqhnya. Banyak diantara mereka hanya mengikuti pendapat-pendapat imam mazhab yang diikutinya.

Sebagai suatu penelitian yang berusaha melakukan pembacaan terhadap suatu kitab klasik, maka secara metodologis penelitian ini menggunakan pendekatan hermeneutik. Maksud hermeneutik di sini adalah pembacaan dan penafsiran sebuah teks untuk mencari dan mendapatkan maksud (yang mendekati) dari penulis teks. Sementara itu dalam upaya pengumpulan data, dipergunakan metode penelitian kepustakaan (library research), yaitu dengan meneliti kitab at-Taqrib karya Abu Syuja al-Isfahani sebagai data primer dan karya para ulama dan sarjana lain yang berkaitan dengan pokok masalah sebagai data sekunder. Untuk menganalisis data yang telah terkumpul digunakan teknik deskriptif-analitis, yaitu mendeskripsikan terlebih dahulu teks-teks kitab at-Taqrib yang mengandung bias gender, kemudian isi dan muatannya dianalisis dan diinterpretasi untuk kemudian diambil kesimpulan.

\section{Hasil dan Pembahasan}

\section{Fiqh dan Perubahan Sosial}

Sebelum membahas secara khusus masalah bias gender dalam kitab atTaqrib karya Abu Syuja al-Isfahani, perlu dikemukakan terlebih dahulu tentang keterkaitan tentang fiqh dengan perubahan sosial kultural, untuk menegaskan bahwa sesungguhnya fiqh merupakan suatu bidang kajian yang kontekstual dan fleksibel, sehingga terus dapat mengalami perubahan, termasuk perubahan pada ketentuan-ketentuan yang bias gender.

Sebagaimana telah dikemukakan bahwa secara garis besar perbedaan fuqaha dalam masalah fiqh dipengaruhi oleh adanya perbedaan metodologi yang digunakan dan latar belakang sosial kultural masing-masing fuqaha. 
Gt. Muhammad Irhamna Husin: Representasi Bias Gender dalam Kitab Fiqh (Studi Terhadap Kitab At-Taqrib Karya Abu Syuja Al Isfahani

Mengenai perbedaan para ulama telah memperbincangkan secara panjang lebar. Kitab yang representatif membahas masalah ini, untuk menyebutkan sebagiannya, adalah al-Insaf fi Bayan Asbab al-Ikhtilaf karya Syah Wallyullah al-Dihlawi, ${ }^{12}$ dan Asar al-Ikhtilaf fi al-Qawaid al-Usuliyyah Ikhtilaf al-Fuqaha, sebuah disertasi Mustafa Said al-Khinn di Universitas al-Azhar Mesir. Namun, karena keterbatasan tempat hal tersebut tidak dibahas, dan disini hanya akan dipaparkan secara sepintas mengenai pengaruh lingkungan sosial kultural terhadap, proses pembentukan fiqh.

Pada awal sejarah pembentukan fiqh, misalnya, sering sekali terjadi perbedaan pendapat antara fuqaha Madinah di satu sisi dan fuqaha Kufah di sisi yang lain. Perbedaan tersebut antara lain menganal hak waris dzawu al-arkam (anggota keluarga dari garis perempuan) ketika tidak ada ahl al-furud dan ashabah. Menurut fuqaha Madinah, dzawu al-arbam tidak akan pernah mendapat warisan, karena Alquran sendiri tidak secara khusus memberikan hak waris kepada mereka. ${ }^{13}$ Sebaliknya, fuqaha Kufah berpendapat bahwa walaupun alquran tidak secara tegas menyebut mereka, namun dengan mengakui adanya hak waris bagi kerabat perempuan yang termasuk ahl al-furud berarti Alquran secara implisit mengakui juga hak waris bagi orang-orang yang dihubungkan dengan kerabat perempuan tersebut, yaitu dzawu al-arkam.

Perbedaan pendapat ini dapat dimengerti, mengingat masyarakat Madinah adalah masyarakat patrilineal, sehingga tidak mudah bagi mereka memberi hak waris kepada orang-orang tersebut. Namun, tidak demikian bagi masyarakat Kufah. Kaum perempuan dalam masyarakat Kufah yang kosmopolitan mempunyai penghargaan dan hak yang lebih baik, sehingga mereka dan kerabat yang melalui mereka dianggap layak memperoleh

\footnotetext{
${ }^{12}$ Syah Wallyullah al-Dihlawi, Al-Insaf Fi Bayan Asbab Al-Ikhtilaj (Beirut: Dar an-Nafais, 1977).

13 Malik Ibn Anas, Al-Muwatta. 27 Kitab Al-Faraid, 12. Bab Mun Ia Mirasalah (Beirut: Dar al-Fikr, 1989), h. 326.
}

Al Qalam: Jurnal Ilmiah Keagamaan dan Kemasyarakatan

Vol. 13, No. 1, Januari-Juni 2019 
Gt. Muhammad Irhamna Husin: Representasi Bias Gender dalam Kitab Fiqh (Studi Terhadap Kitab At-Taqrib Karya Abu Syuja Al Isfahani

warisan. ${ }^{14}$ Apabila dicermati, kedua pendapat tersebut sama-sama merujuk pada Alquran. Namun, karena kondisi sosial kultural yang berbeda, menimbulkan pemahaman yang berbeda pula. Dengan kata lain, dalam hal ini Alquran dipahami dan ditafsirkan dari sudut pandang keadaan sosial setempat. Di sinilah terlihat sifat lokalitas dari historitas bangunan fiqh.

Sejalan dengan masalah di atas, adalah masalah wali bagi perempuan dalam akad pernikahan. Bagi fuqaha Madinah, yang masyarakatnya masih teguh pada konsep-konsep hukum yang mempertahankan sistem kesukuan Arab, berlaku dalam pernikahan merupakan hak prerogatif anggota keluarga laki-laki. ${ }^{15}$ Karenanya, tidak seorang perempuan pun di Madinah yang menikahkan dirinya (melakukan akad pernikahan sendiri), kecuali harus diserahkan kepada walinya. Sementara di Kufah, yang masyarakatnya bersifat heterogen dan campuran dari beberapa ras, norma-norma kesukuan seperti itu terasa asing. Oleh karena itu, walaupun tetap menduduki posisi yang lebih rendah, kaum perempuan di Kufah dalam hal-hal tertentu mempunyai kewenangan atas dirinya, termasuk dalam hal pernikahan. Mereka (kaum perempuan) yang telah dewas diperkenankan melakukan sendiri akad pernikahannya, tanpa harus menyertakan orang wali (laki-laki) dengan syarat kafaah (ada kesetaraan antara calon mempelai laki-laki dan perempuan). ${ }^{16}$ Bahkan di samping dapat melakukan akad nikah sendiri, menurut Abu Hanifah,

14 Noel J. Coulson, A History of Islamic Law (Edinburgh: Edinburgh University Press, 1964), h. 48-49.

15 Fathul Jannah, Kekerasan Terhadap Istri (Yogyakarta: Lkis Pelangi Aksara, 2003), h. 17.

${ }^{16}$ Adanya syarat kafaah (kesetaraan) dalam perkawinan ini pertama sekali berasal dari Kufah. Hal ini timbul karena keragaman masyarakat Kufah yang terdiri dari orang-orang Arab dan non-Arab serta adanya stratifikasi sosial peninggalan kerajaan Persia, Sasaniah, yang melahirkan kesadaran kelas. Konsep hukum seperti ini tidak dikenal oleh fuqaha Madinah awal, karena memang adanya perbedaan kelas tidak dirasakan oleh masyarakat Madinah awal yang teranyam secara rapat. lihat Ibn Rusyd, Bidayah Al Mujtahid Wa Nihayah Al-Muqatashid (Beirut: Dar al-Fikr, 1995), h. 6-7.

Al Qalam: Jurnal Ilmiah Keagamaan dan Kemasyarakatan

Vol. 13, No. 1, Januari-Juni 2019 
Gt. Muhammad Irhamna Husin: Representasi Bias Gender dalam Kitab Fiqh (Studi Terhadap Kitab At-Taqrib Karya Abu Syuja Al Isfahani

perempuan dewasa dapat mengahlmkan anaknya yang masih kecil atau menjadi wakil bagi orang lain untuk menikahkan. ${ }^{17}$

Begitu pula dalam hal dzukurah atau sifat laki-laki sebagai syarat untuk menjadi hakim. Walaupun mayoritas fuqaha berpendapat bahwa sifat laki-laki merupakan syarat sah yang harus dimiliki oleh seorang hakim, namun $\mathrm{Abu}$ Hanifah (w.150 H), tokoh utama fuqaha Kufah, tidak berpendapat demikian. Menurutnya, seorang perempuan dapat menjadi hakim dalam masalah persengketaan harta benda. Bahkan Ibn Jarir al-Thabari (w.310 H) pada masa berikutnya seiring dengan perkembangan zaman berpendapat bahwa perempuan dapat menjadi hakim secara mutlak, dalam arti dapat memutuskan perkara dalam masalah apapun. ${ }^{18}$

Beberapa contoh kasus di atas, dapat dilihat betapa kondisi sosial kultural mempengaruhi suatu produk pemikiran fiqh. Bukti yang paling jelas adalah pribadi Imam asy-Syafii mempunyai qaul qadim di Bagdad dan qaul jadid di Mesir. ${ }^{19}$ Adanya dua pemdapat (qaulani) ini tidak berarti Imam asySyafii bersikap inkonsisten dalam pemikiran fiqhnya. Namun, fiqh memang fleksibel, kontekstual dan harus relevan dengan suatu tempat dan zaman. Walaupun tetap tingkat fleksibilitas pemikiran fiqh dari seorang faqih ditentukan juga oleh metodologi yang dipeganginya. Sikap Imam asy-Syafii ini kemudian diikuti oleh pengikut-pengikut mazhabnya pada masa-masa awal. Mereka, dengan berpegang kapada kaidah-kaidah usuliyyah Imam asy-Syafii, terus mengembangkan dan menetapkan hukum-hukum furu baru seiring dengan

17 Muhammad Ibn Ismail as-Sanani, Subul As-Salam (Kairo: Syirkah Maktabah wa Matbaah Mustafa al-Babi al-Halabi wa Auladuh, 1950), h. 120.

${ }^{18}$ Ibn Rusyd, Bidayah Al Mujtahi..., h. 344 .

${ }^{19}$ Selama Menetap di Bagdad, Beliau mengluarkan ijtihad-ijtihadnya, yang disebut qaul qadim. ijtihad adalah usaha yang dilakukan oleh ahli agama Islam untuk memutuskan suatu perkara yang tida dibahas dalam Alquran dan Hadits. kemudian beliau pindah ke Mesir. beliau melihat masaslah yang berbeda dengan yang ditemui di Bagdad. kemudian beliau melakukan ijtihad-ijtihad yang berbeda disebut qaul jadid. lihat buku Ahmad Nahrawi Abdus Salam Al-Indunisi, Ensiklopedia Imam Syafi'i, diterjemahkan dari al-Imam al-Syafi'i fi Mazhabihi al-Qadim al-Jadid (Jakarta: Hikmah, 2008). 
Gt. Muhammad Irhamna Husin: Representasi Bias Gender dalam Kitab Fiqh (Studi Terhadap Kitab At-Taqrib Karya Abu Syuja Al Isfahani

perkembangan zaman dan selaras dengan tuntutan sosial kultural masingmasing.

Fuqaha Syafiiyyah di Irak dan Mesir dalam penetapan hukumnya terlihat dekat dengan pendapat-pendapat Imam asy-Syafii. Imam asy-Syafii sendiri mengembangkan fiqhnya di dua daerah tersebut, tuntutan sosial kultural yang dihadapi mereka tidak terlalu berbeda dengan masa-masa Imam asy-Syafii hidup. Namun bagi fuqaha Syafiiyyah yang berada di daerah Khurasan dan Naisabur, misalnya, mereka harus berusaha melakukan pengkajian dan penetapan hukum-hukum furu (baru) yang sesuai dengan lingkungan budaya setempat. ${ }^{20}$ Hal ini pada gilirannya menimbulkan kecenderungan yang berbeda di antara fuqaha Syafiiyyah lainnya. Fuqaha kelompok Irak (al-Iraqiyyun) mempunyai kecenderungan ke arah naql (qaul Imam asy-Syafii), sementara fuqaha kelompok Khurasan (al-Khurasaniyyun) mempunyai kecenderungan pada pola pengkajian yang menitikberatkan pada penalaran. ${ }^{21}$

Pengaruh kondisi sosial kultural terhadap proses pembentukan fiqh, sebagaimana terlihat, tidak hanya terjadi pada fuqaha yang mempunyai paradigma dan metodologi berfikir berbeda, seperti antara fuqaha Madinah dan fuqaha Kufah, tetapi juga pada fuqaha yang mempunyai kesamaan metodologi dan paragdigma berfikir seperti terjadi pada inter fuqaha Syafiiyyah. Bahkan, hal itu dapat juga pada diri satu orang, seperti pribadi Imam asy-Syafii dengan qaul qadim dan qaul jadidnya.

Atas dasar itulah, kemudian dalam diskursus fiqh, terutama sebagai landasan kontekstualisasi dan pengembangan pemikirian fiqh, dikenal suatu kaidah mashyur, yakni tagayyur al-ahkam bi tagayyur al-amkinah wa alazminah wa al-ahwal ${ }^{22}$, dan kaidah al-adab muhakkamah ${ }^{23}$. Dua kaidah ini

\footnotetext{
${ }^{20}$ Amandra Mustika Megarani, Kilau Mutiara Sejarah Nabi (Jakarta: Tempo Publishing, 2013), h. i.

${ }^{21}$ Muhammad Abu Zuhrah, Asy-Syafti : Hayatuh Wa Asruh Wa Arduh Wa Fiqhuh (Kairo: Dar al-Fikr al-Arabi, tt), h. 324-325.

${ }^{22}$ Mahmasani, Falsafah At-Taqrib Tasyri Fi Al-Islam..., h. 201.
} 
Gt. Muhammad Irhamna Husin: Representasi Bias Gender dalam Kitab Fiqh (Studi Terhadap Kitab At-Taqrib Karya Abu Syuja Al Isfahani

memang hampir dihapal oleh seluruh pengkaji fiqh sekarang, namun dalam kenyataanya jarang atau bahkan tidak pernah di praktekkan dalam kehidpan sehari-hari.

\section{Representasi Bias Gender dalam Kitab at-Taqrib}

\section{a. Cara membersihkan sesuatu yang Terkena Air Kencing Bayi}

Menurut Abu Syuja, untuk membersihkan air kencing, termasuk air kencing bayi perempuan, adalah dengan dicuci, kecuali air kencing bayi laki-laki yang belum memakan-makanan, maka cukup dibersihkan dengan cara memperciki air di atasnya. ${ }^{24}$ Pandangan Abu Syuja ini memang didasarkan pada teks hadist yang menyatakan bahwa air kencing (bayi) lakilaki cukup diperciki air sementara air kencing (bayi) perempuan harus dicuci. Dalam mengomentari maksud hadist tersebut, Imam asy-Syafii berpendapat bahwa adanya perbedaan dalam membersihkan air kencing bayi laki-laki dan bayi perempuan tersebut adalah karena perempuan (Hawa) diciptakan dari tulang rusuk laki-laki (Adam), sehingga apabila air kencing bayi laki-laki itu berasal dari air dan tanah sementara air kencing bayi perempuan berasal dari daging dan darah. ${ }^{25}$

Pandangan Abu Syuja yang didasarkan pada hadist Nabi dan juga selaras dengan pandangan imam mazhab yang diikuti, yaitu Imam asySyafii, dapat dipastikan bahwa pendapat Abu Syuja ini akan tetap dan tidak akan berubah, karena ia berpegang pada hadist yang membangun pandangannya tentang penciptaan perempuan. Padahal apabila diteliti lebih lanjut, hadist yang menyatakan bahwa perempuan diciptakan dari tulang rusuk atau perempuan diumpamakan sebagai tulang rusuk, adalah hadist yang tidak berkaitan sama sekali dengan awal penciptaan manusia, tetapi

\footnotetext{
1986), h. 256.

24 Abu Syuja al-Isfahani, Fathul Qarib Al-Munjib Fi Syarhil at-Taqrib (Beirut: Dar Ibnu Hazm, tt), h. 10. 188.

${ }^{25}$ Ibnu Majah al-Qazwini, Sunan Al-Mustafa (Beirut: Dar al-Fikr, tt), h. 187-
}

${ }^{23}$ Ali Ahmad an-Nadwi, Al-Qawaid Al-Fiqhiyyah (Damaskus: Dar al-Qalam, 
Gt. Muhammad Irhamna Husin: Representasi Bias Gender dalam Kitab Fiqh (Studi Terhadap Kitab At-Taqrib Karya Abu Syuja Al Isfahani

hadist tentang anjuran kepada para suami untuk berbuat baik kepada para isteri. $^{26}$

\section{b. Perempuan tidak Sah menjadi Imam Salat bagi Laki-laki}

Seorang laki-laki dewasa tidak sah salatnya apabila ia bermakmum kepada perempuan, karena perempuan tidak dapat menjadi imam salat bagi laki-laki. ${ }^{27}$ Pandangan Abu Syuja ini merupakan pandangan mayoritas ulama, seperti Hanafiyyah, Syafiyyah dan lain-lain. ${ }^{28}$ Mereka mendasarkan pandangannya berdasarkan hadist nabi yang menyatakan hal itu. Dengan demikian Abu Syuja memang memiliki pandangan seperti itu walaupun kondisi sosial mengalami perubahan, misalnya perempuan telah banyak yang pandai agama dan masyarakat memandang mereka sejajar dengan laki-laki, karena memang teks hadist yang ia pegangi menyatakan hal itu. Bahkan imam Maliki mengharamkan keras wanita menjadi imam sholat fardhu maupun sholat sunnah. ${ }^{29}$

\section{c. Kelonggaran Syarat Poligami}

Abu Syuja sebagaimana ulama-ulama sezamannya, berpendapat bahwa laki-laki merdeka boleh berpoligami sampai empat isteri dan lakilaki budak boleh mengumpulkan dua isteri. ${ }^{30}$ Abu Syuja dalam hal ini tidak menyebutkan syarat apa-apa yang harus dipenuhi oleh seorang laki-laki untuk melakukan poligami. Hal ini selaras dengan pandangan masyarakat dan para ulamanya saat itu bahwa poligami adalah hak bagi laki-laki yang dapat diambil atau tidak diambil.

Walaupun Abu Syuja mendasarkan pandangannya kepada ayat Alquran, namun ayat Alquran tersebut dipahami sesuai dengan konteks zamannya, sehingga pandangan yang menonjol terhadap ayat tersebut

26 an-Nawawi, Sahih Muslim Bi Syarh An-Nawawi (Beirut: Dar al-Fikr, 1972), h. 57-58.

${ }^{27}$ al-Isfahani, Fathul Qarib Al-Munjib Fi Syarhil at-Taqrib..., h. 17.

28 as-Sanani, Subul As-Salam..., h. 28-29.

${ }^{29}$ Tutik Hamidah, Fiqh Perempuan, Berwawasan Keadilan Gender (Malang: UIN Maliki Press, 2011), h. 63.

${ }^{30}$ al-Isfahani, Fathul Qarib Al-Munjib Fi Syarhil at-Taqrib..., h. 43.

Al Qalam: Jurnal Ilmiah Keagamaan dan Kemasyarakatan

Vol. 13, No. 1, Januari-Juni 2019 
Gt. Muhammad Irhamna Husin: Representasi Bias Gender dalam Kitab Fiqh (Studi Terhadap Kitab At-Taqrib Karya Abu Syuja Al Isfahani

adalah kebolehan poligami itu sendiri tanpa memandang syaratnya, yaitu harus adanya keadilan baik material maupun kasih sayang. Sesungguhnya apabila dilihat secara utuh maka ayat-ayat poligami tersebut mensyaratkan keadilan yang sangat sulit untuk dicapai. ${ }^{31}$ Dengan kata lain Abu Syuja telah melakukan penafsiran terhadap ayat Alquran dengan kebiasaan (urf) dan konteks sosial kultural ketika itu, sehingga apabila konteks sosialnya berubah maka pendapatnya tersebut dapat dipastikan juga berubah. Artinya ia pada gilirannya akan menafsirkan ayat-ayat kebolehan poligami tersebut secara utuh, yaitu adanya pra syarat yang sangat sulit untuk melakukan poligami. Dengan demikian apabila ayat-ayat tersebut dipahami secara cermat, maka pada dasarnya prinsip dalam Islam adalah monogami, dan poligami $^{32}$ hanya dapat dibolehkan apabila dalam keadaan darurat dan syarat yang sangat ketat.

\section{d. Anak Gadis dapat Dipaksa Menikah}

Abu Syuja sesuai dengan pendapat imam mazhab yang diikutinya, yaitu Imam asy-Syafii, berpendapat bahwa bapak dan kakek sebagai wali memiliki hak memaksa (ijbar) untuk menikahkan anak gadisnya ${ }^{33}$. Pendapat ini didasarkan pada hadist nabi yang menyatakan bahwa janda lebih berhak atas (Pernikahan) dirinya dari pada walinya, dan anak gadis selayaknya diajak musyawarah dan izinnya adalah diamnya. ${ }^{34}$ Dari hadist tersebut dapat ditarik pemahaman bahwa apabila janda itu lebih berhak atas dirinya pada walinya, maka sebaliknya wali lebih berhak atas anaknya yang

${ }^{31}$ QS. an-Nisa (4) : 3 dan 129.

32 Poligami adalah sistem perkawinan yang salah satu pihaknya memiliki beberapa lawan jenisnya dalam wantu bersamaan. para ahli membedakan bagi seorang laki-laki yang mempunyai lebih dari satu istri disebut pologini sedangkan perempuan yang mempunyai lebih dari satu orang suami disebut poliandri. lihat buku M. A Tihami and Sohari Sahrani, Fiqh Munakaha: Kajian Nikah Lengkap (Jakarta: Rajawali Pers, 2010).

${ }^{33}$ al-Isfahani, Fathul Qarib Al-Munjib Fi Syarhil at-Taqrib..., h. 45.

${ }^{34}$ al-Biga al-Biga, At-Tazbih Fi Adillah Matn Al-Gayah Wa at-Taqrib (Surabaya: al-Hidayah, tt), h. 163.

Al Qalam: Jurnal Ilmiah Keagamaan dan Kemasyarakatan Vol. 13, No. 1, Januari-Juni 2019 
Gt. Muhammad Irhamna Husin: Representasi Bias Gender dalam Kitab Fiqh (Studi Terhadap Kitab At-Taqrib Karya Abu Syuja Al Isfahani

masih gadis. Dari cara mafhum mukhalafah inilah mazhab Syafii berpendapat adanya wali mujbir.

Pandangan ini seharusnya tidak dipegangi oleh Abu Syuja yang hidup di Basrah. Karena di wilayah Irak secara umum, perempuan dalam hal tertentu termasuk masalah pernikahan ini, mempunyai hak untuk melakukan perbuatannya tanpa disyaratkan wali. Hal ini dapat dilihat dari pendapat Abu Hanifah, Zufar, as-Sabi, dan az-Zuhri yang menyatakan bahwa perempuan dewasa termasuk gadis, dapat menikahkan dirinya tanpa disyaratkan adanya wali. ${ }^{35}$ Dengan demikian pandangan Abu Syuja tersebut akan tetap seperti itu karena ia tidak berusaha merespon kondisi sosial yang ada, tetapi ia hanya mengikuti pendapat imam mazhabnya.

\section{e. Talak tidak dengan Perkataan yang jelas Tidak Perlu Niat}

Menurut Imam Abu Syuja, sebagaimana pendapat dalam mazhab Syafii lainnya, perkataan talaq secara jelas (sarih), yaitu dengan menggunakan kata at-Thalaq, al-Firaq dan as-Sarah, apabila diucapkan oleh seorang suami kepada isterinya maka langsung jatuh talaq walaupun tanpa adanya niat. ${ }^{36}$ Hal ini karena ketiga kata tersebut terdapat secara langsung dalam Alquran dan maksud dari ketiga kata tersebut adalah talaq. ${ }^{37}$ Karenanya, apabila seorang suami mengatakan ketiga kata tersebut kepada isterinya, maka sudah dapat dipastikan bahwa yang dimaksudkan adalah talaq. Namun, ketiga kata tersebut walaupun terdapat dalam Alquran tidak berarti juga menjadi perkataan cerai yang jelas (sarih) bagi orangorang selain Arab. Misalnya, di Indonesia, memang kata al-Talaq telah dikenal luas, sehingga dapat dikatakan sebagai kata yang sarih bagi perceraian. Akan tetapi, kedua kata lainnya tidak biasa digunakan oleh masyarakat Indonesia.

\footnotetext{
${ }^{35}$ Bidayah Al Mujtahid Wa Nihayah Al-Muqatashid..., h. 7.

${ }^{36}$ al-Isfahani, Fathul Qarib Al-Munjib Fi Syarhil at-Taqrib..., h. 47.

${ }^{37}$ Lihat misalnya QS. at-Thalaq (65) : 1-2 dan QS. al-Ahzab (33) : 28.
} 
Gt. Muhammad Irhamna Husin: Representasi Bias Gender dalam Kitab Fiqh (Studi Terhadap Kitab At-Taqrib Karya Abu Syuja Al Isfahani

Pendapat ini berbeda dengan, misalnya, ketetapan Kompilasi Hukum Islam (KHI) pasal 115 dan 117, yang menyatakan bahwa talaq hanya dapat dilakukan di hadapan sidang Pengadilan Agama. Jadi, menurut KHI hanya hakim belaka yang dapat menyatakan keabsahan penjatuhan talaq. Karena itu, pengucapan talaq yang dilakukan seorang suami kepada isterinya, baik di rumah ataupun di dalam surat, belum bisa disebut talaq, melainkan sekedar menunjukkan keinginan untuk menceraikan. Hal ini, antara lain, dimaksudkan untuk melindungi hak-hak isteri dari tindakan sewenang-wenang suami, dan inilah yang dipandang sesuai dengan perkembangan zaman. $^{38}$

\section{f. Diyat yang Diterima Perempuan}

Menurut Abu Syuja diyat (ganti rugi karena dibunuh atau dilukai) yang diterima perempuan adalah setengah dari diyat yang diterima oleh laki-laki. ${ }^{39}$ Pandangan Abu Syuja ini walaupun ada pandangan para sahabat Nabi pada dasarnya berpegang pada adat kebiasaan (urf) saat itu yang membedakan nilai seorang laki-laki dan perempuan. Pandangan ini merupakan pandangan yang umum dipegangi oleh ulama pada saat ini. Mereka biasanya menafsirkan apa yang tersirat dalam QS. al-Baqarah (2) ayat 178 dengan adanya musawah (persamaan), dan mereka memandang bahwa antara laki-laki dan perempuan tidak ada persamaan derajat.

Pandangan tersebut sesungguhnya hanya didasarkan pada penafsiran terhadap maksud ayat yang tersirat, atau dengan kata lain ayat tersebut ditafsirkan berdasarkan kondisi sosial kulturasi ketika itu. Dengan demikian pendapat tersebut, termasuk menurut pendapat Abu Syuja, dapat berubah sesuai dengan berubahnya zaman. Pandangan yang tepat sesungguhnya adalah laki-laki dan keduanya baik laki-laki maupun

${ }^{38}$ Alquran sendiri menyuruh suami, ketika ia menceraikan isterinya, harus dengan cara yang baik (sarahan jamilan) dan secara layak menurut adat kebiasaan (bi maruf). Ukuran baik dan layak tersebut pada dasarnya ditentukan oleh konteks tempat dan zaman.

${ }^{39}$ al-Isfahani, Fathul Qarib Al-Munjib Fi Syarhil at-Taqrib..., h. 54.

Al Qalam: Jurnal Ilmiah Keagamaan dan Kemasyarakatan

Vol. 13, No. 1, Januari-Juni 2019 
Gt. Muhammad Irhamna Husin: Representasi Bias Gender dalam Kitab Fiqh (Studi Terhadap Kitab At-Taqrib Karya Abu Syuja Al Isfahani

perempuan adalah memiliki jiwa (nafs), sementara diyat qiyas menurut QS. al-Maidah (5) ayat 45 berlaku antara jiwa dan jiwa. Ini berarti yang penting adalah manusianya, bukan laki-laki atau perempuan.

\section{g. Status Anak-anak dan Perempuan yang Tertangkap dalam Perang}

Abu Syuja menyatakan bahwa anak kecil dan perempuan yang tertangkap dalam perang, secara otomatis menjadi budak. ${ }^{40}$ Pendapat ini tampaknya didasarkan semata karena adat kebiasaan (urf) saat itu, karena Alquran dan Sunnah Nabi sendiri pada dasarnya menganjurkan ke arah pembebasan budak. Namun hal ini dapat dipahami karena pada saat itu perbudakan, termasuk hukum mengenai anak-anak dan perempuan yang tetangkap dalam perang, tidak hanya masih berlaku di wilayah Islam, tetapi juga merata di wilayah-wilayah yang lain, termasuk di Eropa. ${ }^{41}$ Oleh karena itu, penetapan yang dikemukakan Abu Syuja tidak dimaksudkan untuk diberlakukan terus menerus. Hal ini akan berubah dengan berubahnya kondisi sosial kultural dan perkembangan zaman.

Apabila pendapat Abu Syuja tersebut dibaca pada konteks sekarang, karena didasarkan pada Urf, maka akan ditetapkan sebaliknya, yaitu bahwa anak-anak dan perempuan (Masyarakat Sipil) harus dilindungi dan tidak boleh dijadikan tawanan perang. Bahkan, apabila ada yang berbuat kejam terhadap mereka, ia akan dipandang sebagai penjahat perang. Di samping itu perbudakan pada zaman sekarang ini tidak hanya pada anakanak dan perempuan tetapi juga kepada laki-laki, merupakan perbuatan yang sangat dikecam bertentangan dengan hak-hak asasi manusia.

\footnotetext{
${ }^{40}$ Abu Syuja, at-Taqrib..., h. 59

${ }^{41}$ Munawir Siadzali, Ijtihad Kemanusiaan. Jakarta: Penerbit Paramadina,
} 1997), h. 26. 
Gt. Muhammad Irhamna Husin: Representasi Bias Gender dalam Kitab Fiqh (Studi Terhadap Kitab At-Taqrib Karya Abu Syuja Al Isfahani

\section{h. Aqiqah Bagi Anak Laki-laki dan Anak Perempuan}

Abu Syuja mengatakan bahwa aqiqah bagi anak laki-laki adalah dua ekor kambing sementara bagi anak perempuan cukup satu ekor. ${ }^{42}$ Pandangan ini didasarkan pada hadist Nabi yang menyatakan hal itu. ${ }^{43} \mathrm{Abu}$ Syuja sebagaimana pandangan mayoritas ulama berpendapat adanya perbedaan jumlah kambing untuk aqiqah antara anak laki-laki dan anak perempuan, dan pendapatnya ini akan tetap seperti itu karena didasarkan hadist Nabi.

Hadits yang dijadikan Abu Syuja dan para ulama lainnya itu hanya merupakan salah satu riwayat, karena terdapat riwayat hadist yang lain bahwa baik untuk laki-laki maupun perempuan, aqiqahya sama, yaitu cukup satu ekor kambing. Bahkan menurut Imam Malik pendapat tersebut merupakan kesepakatan para ulama Madinah. ${ }^{44}$ Pendapat inilah yang lebih sesuai, karena pada dasarnya anak laki-laki dan perempuan adalah sama saja, bahkan Nabi sendiri berusaha untuk mengikis pandangan Arab pra Islam yang tidak menghargai sama sekali anak perempuan. Kemudian pada dasarnya masalah aqiqah ini masalah kemampuan orang tua untuk melakukan tasyakkuran atas kelahiran anaknya baik laki-laki maupun perempuan.

\section{i. Syarat Menjadi Hakim}

Salah satu syarat menjadi hakim, menurut Abu Syuja, adalah harus laki-laki (zukurah). ${ }^{45}$ Syarat ini sesungguhnya tidak ada dalam Alquran maupun Sunnah Nabi, sehingga pendapat tesebut bersifat ijtihad dan tampaknya merupakan hasil penafsiran yang diperluas dari hadist Nabi

\footnotetext{
42 al-Isfahani, Fathul Qarib Al-Munjib Fi Syarhil at-Taqrib..., h. 65.

43 al-Biga, At-Tazbih Fi Adillah Matn Al-Gayah Wa at-Taqrib..., h. 246.

${ }^{44}$ Ibn Anas, Al-Muwatta. 27 Kitab Al-Faraid, 12. Bab Mun Ia Mirasalah..., h. 314-315.

45 al-Isfahani, Fathul Qarib Al-Munjib Fi Syarhil at-Taqrib..., h. 65.
} 
Gt. Muhammad Irhamna Husin: Representasi Bias Gender dalam Kitab Fiqh (Studi Terhadap Kitab At-Taqrib Karya Abu Syuja Al Isfahani

"tidak akan beruntung suatu kaum yang menyerahkan urusannya kepada perempuan" yang diriwayatkan oleh Abu Bakrah. ${ }^{46}$

Basrah di daerah Irak perempuan masih dianggap lebih rendah dari laki-laki, namun dalam hal tertentu, termasuk hak menjadi hakim, kaum perempuan diberi kewenangan. Abu Hanifah yang membolehkan perempuan menjadi hakim dalam urusan harta benda dan bahkan at-Tabari sudah berpendapat bahwa perempuan dapat menjadi hakim dalam menyelesaikan urusan apapun. ${ }^{47}$ Ini berarti Abu Syuja lebih cenderung untuk memegangi pendapat imam mazhabnya, yaitu Imam asy-Syafii, dibanding untuk merespon kondisi sosial Basrah. Dengan demikian pendapat Abu Syuja dalam masalah ini memang bias gender, yaitu perempuan sampai kapanpun tidak dapat menjadi hakim, dan tentu saja tidak sesuai untuk diterapkan pada masa sekarang. Bahkan untuk saat ini di Indonesia telah banyak hakim perempuan, termasuk di pengadilan agama.

\section{j. Kompetensi Saksi Perempuan}

Saksi perempuan sama nilainya dengan setengah saksi laki-laki, karena dua orang laki-laki sama nilainya dengan satu orang laki-laki dan dua orang perempuan. ${ }^{48}$ Pandangan Abu Syuja ini, sebagaimana pandangan ulama lainnya, didasarkan pada QS. al-Baqarah (2) ayat 282. Dengan demikian pandangan Abu Syuja ini sampai kapanpun akan tetap seperti itu, karena apabila dilihat dari kerangka metodologi imam mazhabnya, pendapat seperti itu merupakan pendapat yang sudah pasti $\left(q a t^{\prime} i\right)$ karena didasarkan pada ayat yang jelas.

Terlepas dari pandangan di atas, sesungguhnya para ulama sejak dahulu berbeda pendapat dalam memahami ayat-ayat Alquran, apakah yang dipegangi itu keumuman lafaznya yang berarti memegangi pengertian teks yang tersurat ataukah yang dipegangi itu kekhususan sebab turunnya yang

${ }^{46}$ al-Biga, At-Tazbih Fi Adillah Matn Al-Gayah Wa at-Taqrib..., h. 257.

${ }^{47}$ Bidayah Al Mujtahid Wa Nihayah Al-Muqatashid..., h. 344.

${ }^{48}$ Abu Syuja, at-Taqrib..., h. 68.

Al Qalam: Jurnal Ilmiah Keagamaan dan Kemasyarakatan

Vol. 13, No. 1, Januari-Juni 2019 
Gt. Muhammad Irhamna Husin: Representasi Bias Gender dalam Kitab Fiqh (Studi Terhadap Kitab At-Taqrib Karya Abu Syuja Al Isfahani

berarti sangat memperhatikan konteks sosial kultural ketika ayat itu diturunkan. ${ }^{49}$ Dengan demikian ayat tentang kompetensi saksi perempuan yang setengah dari laki-laki ini masih mengandung kemungkinan untuk direinterpretasi.

\section{Penutup}

Fiqh merupakan produk pemikiran fuqaha yang proses pembentukannya berkaitan erat dengan kondisi sosial kultural, disamping metodologi yang digunakan. Fiqh pada dasarnya adalah hasil pemahaman dan interpretasi para ahli fiqh terhadap Alquran dan as-Sunnah untuk merespon tantangan zamannya. Namun demikian karena kitab at-Taqrib itu dikarang oleh seorang ahli fiqh dan tingkatan muttabi dalam mazhab Syafii maka tidak semua penetapan hukum yang ada didalamnya dimaksudkan untuk merespon tantangan zaman ketika itu dengan menggunakan metodologi imam mazhab yang diikutinya.

Apabila dilihat dari perspektif gender dengan menggunakan pendekatan hermeneutik adakalanya memang karena dipengaruhi oleh kondisi sosial kultural saat itu yang tidak dapat dihindari oleh Abu Syuja dan adakalanya karena Abu Syuja sendiri yang memiliki pandangan bias gender. Karena itu pandangan-pandangan yang bias gender dalam kitab at-Taqrib di samping ada yang harus dibaca sesuai dengan konteks zamannya juga ada yang memang perlu dikaji ulang, baik pengkajian ulang tersebut cara studi komparasi dengan pendapat-pendapat, fuqaha lain maupun dengan melakukan reinterpretasi terhadap dalil dan argumen-argumen yang digunakan.

${ }^{49}$ Zuhairi Misrawi, Alquran kitab toleransi (Jakarta: Grasindo, 2010), h. 67. 
Gt. Muhammad Irhamna Husin: Representasi Bias Gender dalam Kitab Fiqh (Studi Terhadap Kitab At-Taqrib Karya Abu Syuja Al Isfahani

\section{Daftar Pustaka}

Al-Indunisi, Ahmad Nahrawi Abdus Salam. Ensiklopedia Imam Syafi'i, diterjemahkan dari al-Imam al-Syafi'i fi Mazhabihi al-Qadim al-Jadid. Jakarta: Hikmah, 2008.

an-Nawawi. Sahih Muslim Bi Syarh An-Nawawi. Beirut: Dar al-Fikr, 1972.

Biga, al-Biga al-. At-Tazbih Fi Adillah Matn Al-Gayah Wa at-Taqrib. Surabaya: al-Hidayah, tt.

Bruinassen, Martin Van. Kitab Kuning: Pesantren Dan Tarekat. Bandung: Mizan, 1995.

Coulson, Noel J. A History of Islamic Law. Edinburgh: Edinburgh University Press, 1964.

Dihlawi, Syah Wallyullah al-. Al-Insaf Fi Bayan Asbab Al-Ikhtilaj. Beirut: Dar an-Nafais, 1977.

Hamidah, Tutik. Fiqh Perempuan, Berwawasan Keadilan Gender. Malang: UIN Maliki Press, 2011.

Ibn Anas, Malik. Al-Muwatta. 27 Kitab Al-Faraid, 12. Bab Mun Ia Mirasalah. Beirut: Dar al-Fikr, 1989.

Ibn Rusyd. Bidayah Al Mujtahid Wa Nihayah Al-Muqatashid. Beirut: Dar alFikr, 1995.

Isfahani, Abu Syuja al-. Fathul Qarib Al-Munjib Fi Syarhil at-Taqrib. Beirut: Dar Ibnu Hazm, tt.

Izomiddin. Pemikiran dan Filsafat Hukum Islam. Jakarta: Kencana, 2018.

Jannah, Fathul. Kekerasan Terhadap Istri. Yogyakarta: Lkis Pelangi Aksara, 2003.

Jauziyyah, Ibnu Qayyim al-. I'lam Al-Muwaqqi'in an Rabbil 'Alamin. Beirut: Dar al-Jail, tt.

Al Qalam: Jurnal Ilmiah Keagamaan dan Kemasyarakatan Vol. 13, No. 1, Januari-Juni 2019 
Gt. Muhammad Irhamna Husin: Representasi Bias Gender dalam Kitab Fiqh (Studi Terhadap Kitab At-Taqrib Karya Abu Syuja Al Isfahani

KTB, PISS, and TIM Dakwah Pesantren. Tanya Jawab Islam: Piss KTB. Yogyakarta: Daarul Hijrah Technology, 2015.

Mahmasani, Subhi. Falsafah At-Taqrib Tasyri Fi Al- Islam. Beirut: Dar Alquran Ilm li al-Malayin, 1961

Megarani, Amandra Mustika. Kilau Mutiara Sejarah Nabi. Jakarta: Tempo Publishing, 2013.

Misrawi, Zuhairi. Alquran kitab toleransi. Jakarta: Grasindo, 2010.

Nadwi, Ali Ahmad an-. Al-Qawaid Al-Fiqhiyyah. Damaskus: Dar al-Qalam, 1986.

Qazwini, Ibnu Majah al-. Sunan Al-Mustafa. Beirut: Dar al-Fikr, tt.

Sanani, Muhammad Ibn Ismail as-. Subul As-Salam. Kairo: Syirkah Maktabah wa Matbaah Mustafa al-Babi al-Halabi wa Auladuh, 1950.

Sumitro, Warkum, Moh Anas Kholish, and In'amul Mushoffa. Konfigurasi Fiqih Poligini Kontemporer: Kritik Terhadap Paham Ortodoksi Perkawinan Poligini di Indonesia. Malang: Universitas Brawijaya Press, 2014.

Syam, Nur. Madzhab-Madzhab Antropologi. Yogyakarta: Lkis Pelangi Aksara, 2007.

Tihami, M. A, and Sohari Sahrani. Fiqh Munakaha: Kajian Nikah Lengkap. Jakarta: Rajawali Pers, 2010.

Tolchah, Moch. Dinamika Pendidikan Islam Pasca Orde Baru: Pendidikan. Yogyakarta: Lkis Pelangi Aksara, 2015.

Waluya, Bagja. Sosiologi: Menyelami Fenomena Sosial di Masyarakat. Bandung: PT Grafindo Media Pratama, 2007.

Zuhrah, Muhammad Abu. Asy-Syafti: Hayatuh Wa Asruh Wa Arduh Wa Fiqhuh. Kairo: Dar al-Fikr al-Arabi, tt. 